\title{
Religious Moderation in the Framework of Bhinneka Tunggal Ika in Indonesia
}

\author{
I Komang Widyana ${ }^{1}$, I Made Darsana ${ }^{2}$, I Gede Arya Juni Arta ${ }^{3 *}$ \\ ${ }^{1,3}$ Lecturer of Hindu Religious Philosophy Departement, Faculty of Dharma Duta and Brahma Widya \\ ${ }^{2}$ Lecturer of Cultural and Religious Tourism Departement, Faculty of Dharma Duta and Brahma Widya \\ Institut Agama Hindu Negeri Tampung Penyang Palangka Raya \\ Kalimatan Tengah, Indonesia \\ *Corresponding author.Email: aryaskeptisisme@gmail.com
}

\begin{abstract}
Indonesia is an archipelago consisting of various ethnicities and religions. Where Pancasila as the nation's ideology states that the state is based on the One Godhead, which means that every religion in Indonesia has the same belief in One God. This meeting point is what unites multicultural life. Unity in this diversity, if not cared for properly, will lead to disintegration in the nation and state, especially the emergence of the phenomenon of radical understandings in society. In this case, the idea of religious moderation becomes important as a unifying foundation in the Unitary State of the Republic of Indonesia. This study aims to describe the idea of religious moderation and its actualization in the framework of Bhinneka Tunggal Ika in Indonesia. The method used is a literature study. This study concludes that in the life of multiculturalism, the role of religion is very important in shaping people's awareness to accept differences as a unity (Bhinneka Tunggal I $\mathrm{ka}$ ). The idea and attitude of religious moderation in the form of acknowledgment of diversity as a gift from God Almighty can be synthesized to deradicalize. Thus it will establish a life of harmony, tolerance, and mutual respect in all differences.
\end{abstract}

Keywords: Bhinneka Tunggal Ika, Religious Moderation.

\section{INTRODUCTION}

Indonesia is a unitary state based on the Pancasila ideology which is the view of life as a nation and state. Pancasila houses all the various ethnic groups, cultures, and customs within the framework of Bhinneka Tunggal $I k a$, which accepts differences as unity. The Pancasila ideology also sheds light on the plurality of religions in Indonesia in an esoteric unity towards the One God. This means that Indonesia is not a religious state that only adheres to one particular religious understanding as to the state religion, but the Indonesian state is based on the belief in the existence of One God.

The state constitution also guarantees this, wherein the 1945 Constitution, especially in article 29 which gives freedom for every citizen to choose and embrace religion by their respective beliefs with full awareness and without coercion from any party. This is very much in accord with the Indonesian society which is heterogeneous and multicultural, as well as the diverse socio-geographical conditions of Indonesia and is spread out as an archipelagic country. In this case, Indonesia can be said to be one of the largest multicultural countries in the world. Indonesia can also be considered as the country that upholds religious tolerance the most. Given that Indonesia is a country with the largest Muslim population in the world, it gives equal rights to every citizen of a different religion.

The differences in various cultures, ethnicities, customs, and religions are a blessing and a gift from God to be grateful for. Where these differences make
Indonesia even richer and more beautiful. Even so, if this difference is not properly guarded and cared for by all parties, it can lead to horizontal conflict. The emergence of radical ideas (radicalism) in society must be watched out for because it is a serious threat to the Republic of Indonesia. Sumanto in Widodo states that society must unite to face radical groups who like to commit acts of violence and intolerance. Where this is done by a small group of people, often in the name of democratic and religious freedom, to impose their will [1].

Radical ideology not only threatens the integrity of the nation and state but also poses a threat to the existence of religion itself. Where the radical understanding of religion as described by Kimbal will lead to wars between religious communities in the name of a "holy war" which in modern history was carried out by terrorists such as Al-Qeda, ISIS, and its affiliates. In this regard, the Indonesian government has designed preventive or persuasive measures to deradicalize, by discouraging and instilling an attitude of moderation in religion [2]. Based on this background, this study seeks to describe the concept of religious moderation and its application to maintain a harmonious and harmonious life of the nation and state in Indonesia. 


\section{LITERATURE REVIEW}

\subsection{Religious Moderation}

The word religious moderation has recently been discussed massively by the Ministry of Religion of the Republic of Indonesia on various occasions, both through speeches, dialogues, seminars, and writings. The drafting team of the Ministry of Religion of the Republic of Indonesia in their book "Religious Moderation" states that the word moderation comes from the Latin "moderatio", which means neither strength nor weakness [3]. The word also means selfcontrol from an attitude of very strengths and weaknesses. The Big Indonesian Dictionary (KBBI) provides two meanings for the word moderation, namely: reducing violence and avoiding extremes. Moderation in the English word "moderation" is often used in the sense of average, core, standard, or nonaligned. Moderate in general means promoting balance in terms of beliefs, morals, and character, both when treating others as individuals, and when dealing with state institutions. This word in Arabic is known as the word "wasath" or "wasathiyah", which has the equivalent meaning of the words "tawassuth" (middle), "i'tidal" (fair), and "tawazun" (balanced). In Arabic too, the word wasathiyah is defined as the best choice. Referring to this, all of them imply the same meaning, namely fair, which in this context means choosing a middle ground position among the various extreme choices that exist.

Mohammad Hashim Kamali in the book "The Middle Path of Moderation in Islam", emphasized that moderate, which in Arabic means "wasathiyah", is related to two keywords, namely balanced and fair. Moderate does not mean compromise with the main principles (ushuliyah) of religious teachings which are believed to be tolerant towards people of other religions, but moderate means “... confidence, right balancing, and justice..." [1]. Based on this, it can be understood that moderation is a balanced religious attitude between inward belief and outward tolerance. In the terminology of the perennial philosophy, this is often said to be "relatively absolute", that is, absolute or inwardly exclusive, and becomes inclusive when it is put on the outside.

This balance or middle way in religious practice will undoubtedly prevent oneself from excessive extremes, fanatics, and revolutionary attitudes in religion. Religious moderation is a solution to the presence of two poles of extremes in religion, the ultra-conservative pole or the extreme right on the one hand, and the liberal or the extreme left on the other. Religious moderation is the key to creating tolerance and harmony, both at the local, national, and global levels. The choice of moderation by rejecting extremism and liberalism in religion is the key to balance, for the sake of maintaining civilization and creating peace. In this way, each religious community can treat others with respect, accept differences, and live together in peace and harmony. In a multicultural society like Indonesia, religious moderation is not only a choice but a necessity [3].
Moderation is not only taught by Islam but also in other religions. Furthermore, moderation is a virtue that encourages the creation of social harmony and balance in personal, family, and community life to wider human relations [3]. Based on this, all religions must strive to emphasize a moderate perspective and behavior towards their followers, considering that harmony and harmony in life in a multi-religious society such as in Indonesia will only be created if all people can be balanced and fair seeing the others. This justice and balance will give birth to an attitude of mutual respect, tolerance, tolerance, empathy, and sympathy between religious communities within the framework of the Republic of Indonesia.

\subsection{Bhineka Tunggal Ika}

Bhinneka Tunggal Ika is the motto of the Indonesian nation, is symbolically written on the national emblem, which is on the ribbon inscribed on the grip of the Garuda Pancasila bird's leg. This is constitutionally regulated in article 36A of the 1945 Constitution which reads: "The National Symbol is the Garuda Pancasila with the motto "Bhinneka Tunggal Ika". Sujanto in Lestari explains that: "Bhinneka Tunggal Ika is the slogan of the state institutions of the Republic of Indonesia which are determined based on Government Regulation no. 66 of 1951, which means even though it is different but it is still one. In this regard, "the building of an Indonesian insight is the manifestation of a common desire to be able to realize unity or oneness. The unity of diversity becomes an agreed-upon unit, namely Indonesia". Where is the source of origin of Sesanti Bhinneka Tunggal Ika taken from the Sutasoma Book which was written in the 14th century by Empu Tantular in the Majapahit era [4].

The motto "Bhinneka Tunggal Ika" when analyzed etymologically comes from Sanskrit. This word consists of "bhinneka", "tunggal", and "ika". Where the word "bhinneka" comes from the word "bhinna" and "ika". "Bhinna" means different things and "ika" means that. So, the word "bhinneka" means different things. Another analysis shows that the word "bhinneka" consists of elements of the word "bhinn-a-eka". The element " $a$ " means no, and "eka" means one. Thus, the word "bhinneka" can also mean that is not one. Meanwhile, the word "tunggal" means one, and "ika" means that. Based on this analysis, it can be concluded that the motto "Bhinneka Tunggal Ika" means the differences in that one or diverse but one nonetheless [5].

The word Bhinneka Tunggal Ika historically describes the diversity of the Majapahit era and was later used as a unifying nation during the independence era of the Republic of Indonesia. Lestari explains that historically, the people of the archipelago have been aware of plurality, multiethnicity, and multi-religion for a long time [4]. This awareness of diversity was raised again during the struggle for independence to explore the spirit of unity of the Indonesian nation. Colonial colonialism gave a sense of the same fate as the nation's condition. The emergence of ideas and resistance movements up to the Youth Pledge Congress was implemented as an initiative of Indonesian youth at that 
time. In this case, the Sasanti Bhinneka Tunggal Ika, not just a theoretical value, but a praxis that is actualized into the real life of the Indonesian nation daily.

Bhinneka Tunggal Ika is a must-lived and recognized nation within the Unitary State of the Republic of Indonesia. Where the diversity of cultures, customs, tribes, languages, and religions is part of God's grace that must be cared for and maintained as a gift to the Indonesian people. In this case, the existence of differences is to complement and strengthen one another, not the other way around negating. Based on this, the spirit of Bhinneka Tunggal Ika becomes the soul and view of life in the nation, state, and homeland. Where the spirit of accepting differences as a unity in the nation, state, and homeland is the foundation of strength to maintain the integrity of the Republic of Indonesia.

\section{METHOD}

This research used the library method, namely: 1) the research was carried out by tracing the text (manuscript) and not by direct excavation from the field source or the scene of the incident, 2) the library data was ready to use, 3) the library data in this study were the main source of primary data. Based on this, in this study, various data and information on religious moderation were collected from literature, such as journals and other studies that correlate with this research. The data that has been collected is then processed and outlined in descriptive, narrative, and argumentative forms.

\section{RESULT AND DISCUSSION}

The emergence of attitudes and understandings of radicalism in religion is a threat to the diversity and integrity values of the Republic of Indonesia. Radicalism itself can be understood as a notion or ideology that contrasts sharply or radically between the ideas adhered to by certain groups and the prevailing and steady values order today [1]. Differences in views in a democratic realm are things that inevitably happen, as long as this in Indonesia is based on the ideology of Pancasila and the Republic of Indonesia. The strengthening of radicalism becomes dangerous when it is opposed to the values of Pancasila, such as the emergence of an intolerant attitude that does not hesitate to use violence to achieve the goals of the ideology that is espoused. In this case, terrorism is an inseparable part of the implications of this radicalism.

Radicalism can emerge in every country and every religion. This can be triggered by various factors like the background. Bahtiar Effendy in Widodo explains that there are at least 3 tendencies for the emergence of radicalism. First, radicalism is a response to ongoing conditions [1]. Usually, this response appears in the form of evaluation, rejection, or even resistance. Second, radicalism does not stop at resistance but continues to try to replace the existing value order with another form of order. Third, the strength of the radicalized belief in the correctness of the program or ideology they adhere to and believe. This attitude is at the same time accompanied by denial of the truth in other systems that will be replaced.

In response to this, the state through the government needs to take appropriate and measured actions, either persuasively or repressively. Repressive measures will be carried out for terrorism which directly threatens the safety and lives of the Indonesian people, while massive persuasive and preventive measures are taken to prevent radicalism. In this case, this can be done through teaching in educational institutions, lectures, discussions, workshops, dialogue, and socialization on religious moderation. Where the understanding of religion which is in the middle, balanced and fair is believed to be able to prevent radical understandings or in deradicalization efforts for those previously exposed to radicalism.

Cultivating an attitude of religious moderation can be done from and from an early age, both informal and non-formal education starting from the family circle. In this case, the method used can adapt to each religion. Sutrisno explains that the form of moderation can vary from one place to another because the parties facing it and the problems faced are not identical from one country to another. In Muslim-majority countries, this moderation includes at least several things, such as recognition of the existence of other (religious) parties, having a tolerant attitude, respecting differences of opinion, and not imposing their will using violence [6].

In Indonesia, religion is the main guideline in the framework of Pancasila, which is based on the precepts of God Almighty. Religion becomes a guide and guideline to achieve a balance between the profane and the sacred. This is following the aim of bringing down religious teachings to the world to answer various human problems, both at the micro and macro scale, the family (private) and the state (public) [7]. It is in this case that the understanding of religious moderation is very important in the midst of religious life in multicultural Indonesia. Where religious moderation teaches not only to act in the middle (moderate) but also in a balanced and fair manner. The awareness to always act in the middle, balance, and fairness is what will create a sense of tolerance and behavior amid differences so that harmony becomes a necessity in the Unitary State of the Republic of Indonesia.

Religious moderation is very important and strategic in maintaining diversity in Indonesia. The concept of religious moderation in Indonesia can be a reference for other countries, which still put forward the ideology of the left and the right. Indonesia as a heterogeneous and multicultural nation has been successfully united through the concepts of Pancasila and Bhinneka Tunggal $I k a$ in the Unitary State of the Republic of Indonesia (NKRI) by the nation's founders, and the next generation must protect it through the actualization of Pancasila values in everyday life. which of them can be done with religious moderation behavior, to create a harmonious, peaceful, harmonious, and friendly national and state life [8]. 


\section{CONCLUSION}

The strengthening of radicalism in religion in Indonesia must be addressed carefully and appropriately. In this case, the government and all related stakeholders need to explore and analyze the root of the problem and then take measurable and appropriate steps. If religious radicalism is allowed to be ignored, it can undermine and destroy the harmony and order in the nation and state. Thus, religious moderation is very important to do. Where religious moderation is not limited to necessity but becomes a necessity for every religion. In this case, religious moderation teaches a middle way, balanced and fair attitude in viewing diversity as a unity. This is in accordance with the values of Pancasila and Bhinneka Tunggal Ika. Thus, there will be harmony and awareness of the nation and land within the framework of the Unitary State of the Republic of Indonesia.

\section{REFERENCES}

[1] Widodo, Priyantoro dan Karnawati. "Moderasi Agama dan Pemahaman Radikalisme di Indonesia". PASCA: Jurnal Teologi dan Pendidikan Agama Kristen, Vol.15, no 2, 2019

[2] Kimball, Charles. 2013. Kala Agama Menjadi Bencana. Terjemahan Nurhadi dan Izzuddin Washil. Mizan Pustaka: Bandung.

[3] Tim Penyusun Kementerian Agama. 2019. Moderasi Beragama. Badan Litbang dan Diklat Kementerian Agama RI: Jakarta

[4] Lestari, Gina. "Bhinneka Tunggal Ika: Khasanah Multikultural Indonesia di Tengah Kehidupan Sara". Jurnal Pendidikan Pancasila dan Kewarganegaraan, Vol 28, no 1, 2015

[5] Pursika, I Nyoman. "Kajian Analitik Terhadap Semboyan Bhinneka Tunggal Ika". Jurnal Pendidikan dan Pengajaran, Vol.42, no. 1, 2009

[6] Sutrisno, Edy. "Aktualisasi Moderasi Beragama di Lembaga Pendidikan”. Jurnal Bimas Islam, Vol. 12, no. 2, 2019

[7] Akhmadi, Agus. "Moderasi Beragama Dalam Keragaman Indonesia". Jurnal Diklat Keagamaan, Vol. 13, no. 2, 2019

[8] Abror, Mhd. "Moderasi Beragama Dalam Bingkai Toleransi (Kajian Islam dan Keberagaman). Rusydiah: Jurnal Pemikiran Islam. Vol. 2, no.1. 2020 